\title{
Community Structure and Biodiversity of Soil Ciliates at Dongzhaigang Mangrove Forest in Hainan Island, China
}

\author{
Jing Li, ${ }^{1}$ Qingyu Liao, ${ }^{1,2}$ Mei Li, ${ }^{3}$ Jinhong Zhang, ${ }^{2}$ Nora Fungyee Tam, ${ }^{4}$ and Runlin Xu1 \\ ${ }^{1}$ School of Life Sciences, Sun Yat-Sen University, Guangzhou 510275, China \\ ${ }^{2}$ Research Center of Ecology and Environment, Guangzhou Research Institute of Environment Protection, Guangzhou 510620, China \\ ${ }^{3}$ The Research Institute of Tropical Forestry, The Chinese Academy of Forestry, Guangzhou 510520, China \\ ${ }^{4}$ Department of Biology and Chemistry, City University of Hong Kong, Kowloon, Hong Kong \\ Correspondence should be addressed to Runlin Xu, xurunlin_1960@yahoo.com
}

Received 18 November 2009; Revised 7 March 2010; Accepted 30 March 2010

Academic Editor: Yongchao Liang

Copyright ( $) 2010$ Jing Li et al. This is an open access article distributed under the Creative Commons Attribution License, which permits unrestricted use, distribution, and reproduction in any medium, provided the original work is properly cited.

The distribution of soil ciliates in three different habitats within a typical mangrove forest in Dongzhaigang, Hainan, China was investigated. The abundance, biodiversity, and community similarity of ciliates in fresh and air-dried soil with different, physical/chemical properties were analyzed. Three Classes, 11 Orders, 34 Genera, and 70 species of ciliates were found with the first dominant group being Hypotrichida. Ciliate biodiversities followed Site B $<$ Site A $<$ Site C in both fresh and dried samples. Ciliate abundance was positively correlated with soil moisture, salinity, organic matter (OM), total nitrogen (TN), total phosphorus (TP), and sulfate $\left(\mathrm{SO}_{4}{ }^{2-}\right)$, but negatively with $\mathrm{pH}$ and total potassium (TK). Site A and Site B and Site B and Site C showed the highest similarity in fresh and dried samples, respectively. The ubiquitous characteristics of ciliate distribution suggested their important role in food webs and nutrient cycling. The presence of Colpodida was linked with mangrove plants.

\section{Introduction}

Mangrove ecosystems are typical wetland systems in coastal deposits of mud and silt throughout the tropics and subtropical latitudes. They play an important role in maintaining and improving biological environments, purifying air, and resisting wastewater pollution and natural disasters in bays or estuary areas. They are treated as "maritime forests" for their special ecological, economical, and tourist values [1]. The importance of mangroves has attracted increasing attention in recent years, especially after the recent huge tsunami in Indian Ocean [2]. More and more research has been conducted on mangrove ecosystems.

Although all major groups of mangrove plants and animals have been studied to some extent [3-7], little information is available on single-celled soil protozoan organisms except a few described species of foraminifera, amoeboid, and ciliated protists [8-11]. Investigations on soil ciliates in mangrove forest habitats are rare.

Being an important group in nutrient cycling, energy flow, and food webs $[12,13]$, soil ciliates have participated in the decomposition of benthic residual deposit and the formation and development of mangrove soil and accelerated the mineralization processes of carbon, nitrogen, and other mineral nutrient elements [14]. As the main bacterial consumers, soil ciliates also have special characteristics such as high respiration, short generation times, and rapid multiplication. In the rhizosphere of living plants, protozoa play an important role in the mineralization of mineral nutrient elements. The pot experiments of Ekelund and Rønn [14] showed that organic matter released by plants could stimulate bacterial and ciliate activity in the root zone leading to mineralization of organic soil nitrogen and assimulation by plants. The prominent effect brought by soil ciliates may be important in mangrove plant nutrition; on other hand, the growth of plants may also significantly affect the soil quality and ciliate community. The plant roots and soil ciliate community are interdependent.

Moreover, they are good bioindicators of soil environments [15-17]. It is important to study the community structure of soil ciliates and their significance in soil environments, to have a better understanding of the function of 


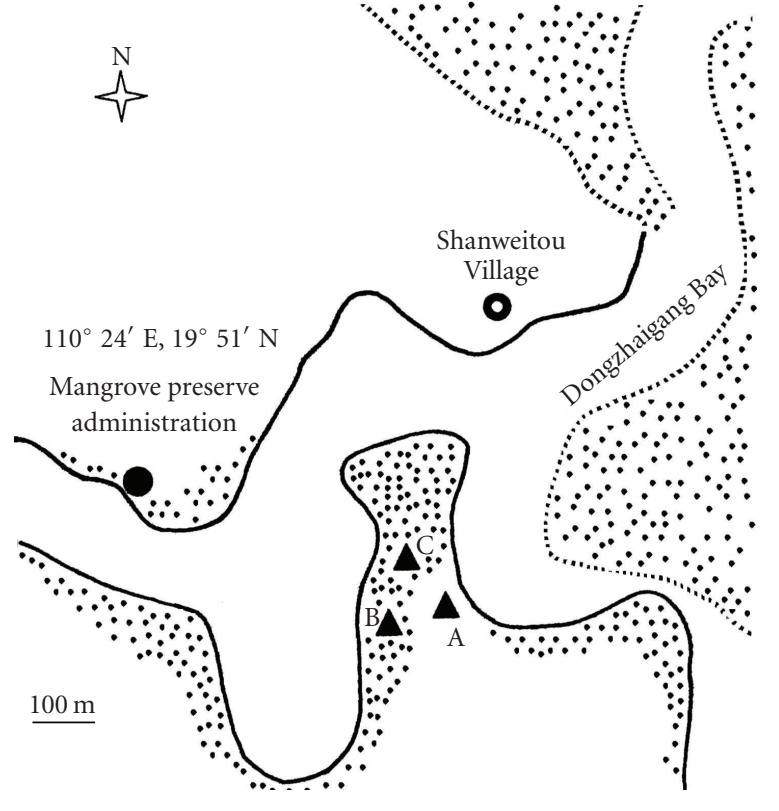

$\because$ Mangrove planted area

Figure 1: Map of sampling sites (A, B, and C) [10].

the mangrove ecosystem and so help in protecting mangrove resources. The present study aims to investigate the species abundance, biodiversity and community similarity index of soil ciliates in a typical mangrove forest in Dongzhaigang, Hainan Island in China. The study also attempts to compare the difference in ciliates community among three different habitats, bare land, and planted and natural mangroves, within forest and relates the ciliate abundance to soil properties.

\section{Materials and Methods}

2.1. Descriptions of Study Area and Soil Sampling. Dongzhaigang $\left(110^{\circ} 30^{\prime}-110^{\circ} 37^{\prime} \mathrm{E}, 19^{\circ} 51^{\prime}-20^{\circ} 01^{\prime} \mathrm{N}\right)$, is a shoal-water bay formed by continental sink during the Great Qiongzhou Earthquake of 1605 . The total everglade area is $5400 \mathrm{~m}^{2}$, with $2065 \mathrm{~m}^{2}$ of mangrove forest, and $3335 \mathrm{~m}^{2}$ of mudflat and shoal water area. Dongzhaigang has a typical subtropical monsoon marine climate. annual average air temperature ranges from $23.3^{\circ} \mathrm{C}$ to $23.8^{\circ} \mathrm{C}$; Annual average rainfall

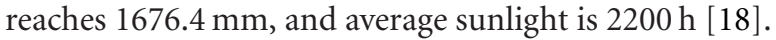

Soil samples were collected from three different habitats in Dongzhaigang National Mangrove Nature Reserve in April and September 2006 (Figure 1). Site A was bare land without any vegetation; Site B was a Sonneratia apetala mangrove forest artificially planted (at a distance between two trees of $2.5 \mathrm{~m}$ apart) by the Reserve three years ago and reached $2 \mathrm{~m}$ tall; Site $\mathrm{C}$ was a natural mangrove habitat dominated by Bruguiera gymnorrhiza with a few individuals of Ceriops tagal. The three sites were located within a triangle of about $100 \mathrm{~m}$ from each other. The sampling area of each sample site was about $10 \mathrm{~m}^{2}$, and ten replicated surface soil samples
$(0-5 \mathrm{~cm})$ with fine plant roots were collected using the "parallel leaping method" $[15,19]$. Because only surface soil samples $(0-5 \mathrm{~cm})$ were needed, instead of a soil corer, here a shovel had been used to collect soil samples. The ten replicated surface soil samples were mixed round equably and combined to a composite sample in the field, then immediately collected about $3 \mathrm{~kg}$ of this composite sample, and immediately placed inside a sterilized plastic bag, sealed and transferred back to the laboratory [19]. Fresh samples were analyzed immediately; the remaining portions were airdried for at least one month and then analyzed.

2.2. Analysis of Physical/Chemical Parameters of Soil Samples. The following soil properties of each soil samples were determined according to standard procedures [20]. Each pooled sample was hand cleaned of plant fragments and pebbles, weighed, dried at $60^{\circ} \mathrm{C}$ for $72 \mathrm{~h}$, and reweighed to determine the moisture content. The $\mathrm{pH}$ and salinity values were obtained using a $1: 5$ soil/water solution by electrical conductivity (automatic, temperature-compensated conductivity meter). Analyses of organic matter were conducted using the acid-dichromate oxidation method, total nitrogen (TN) using the semi-micro kjeldahl method, total phosphate (TP) using the ammonium molybdate spectrophotometry method, total potassium (TK) using the flame photometer method, and $\mathrm{SO}_{4}{ }^{2-}$ using barium sulfate turbidity. Soil mechanical composition of each dried sample was analyzed by a hydrometer method.

2.3. Qualitative Investigations of Soil Ciliates. All samples, both fresh and air-dried, were qualitatively analyzed following the "nonflooded Petri dish method" described by Foissner [15]. About 100-150 g soil sample was placed in a Petri dish (15-20 cm in diameter), saturated but not flooded with distilled water. About $2 \mathrm{~mL}$ of the run-off from each culture was collected on days $2,4,7,14,21$, and 28 for the determination of ciliate species $[15,19]$. The live specimens were observed under a high-power oil-immersion objective with bright field, phase contrast, or differential interference contrast microscopy (magnifications of $\times 40-1000$; Nikon, YS2-H and E800) and complemented with silver line staining [21]. The identification, nomenclature and terminology of ciliate species were done according to the following: Berger [22], Carey [23], Foissner [21], Kahl [24], Lee et al. [25], Shen and Gong [26] Shen et al. [27], and Song [28].

2.4. Quantitative Investigations of Soil Ciliates. The quantitative analysis of soil ciliates was based on the modified "most probable number" (MPN) method employed by Darbyshire et al. [29]. According to our preliminary experiment, dilution factors of $10^{2}-10^{4}$ were adopted for both fresh and air-dried soil samples.

2.5. Data Processing and Statistical Analyses. The Margalef formula [30] was used to calculate ciliate community diversity index:

$$
d=\frac{(S-1)}{\ln N},
$$


TABLE 1: Main physical/chemical factors at the three habitats of the mangrove forest [10].

\begin{tabular}{lccc}
\hline $\begin{array}{l}\text { Environmental } \\
\text { factors }\end{array}$ & Bare land & $\begin{array}{c}\text { Man-made } \\
\text { mangrove }\end{array}$ & $\begin{array}{c}\text { Natural } \\
\text { mangrove }\end{array}$ \\
\hline $\mathrm{pH}$ & 6.51 & 6.16 & 4.77 \\
Water & 24.2 & 35.6 & 45.4 \\
percentage (\%) & 19.243 & 25.695 & 24.288 \\
Salinity & 31.267 & 42.087 & 150.276 \\
$\mathrm{OM}\left(\mathrm{g} \mathrm{Kg}^{-1}\right)$ & 1.345 & 0.831 & 3.962 \\
$\mathrm{TN}\left(\mathrm{g} \mathrm{Kg}^{-1}\right)$ & 0.511 & 0.568 & 0.626 \\
$\mathrm{TP}\left(\mathrm{g} \mathrm{Kg}^{-1}\right)$ & 13.094 & 11.953 & 11.652 \\
$\mathrm{TK}\left(\mathrm{g} \mathrm{Kg}^{-1}\right)$ & 2.001 & 2.895 & 5.503 \\
$\mathrm{SO}_{4}{ }^{2-}\left(\mathrm{g} \mathrm{Kg}^{-1}\right)$ & & & \\
\hline
\end{tabular}

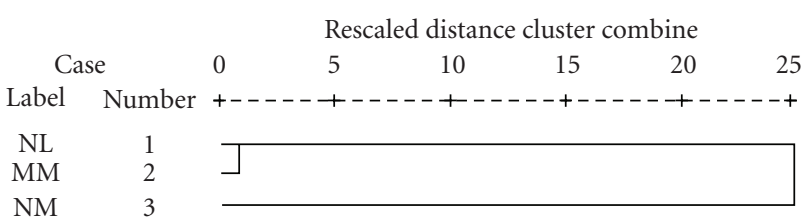

Figure 2: The dendrogram showing the cluster analysis of soil physical/chemical properties at 3 sites.

where $d$ is the diversity index; $S$ is species number; $N$ is total number of individuals of all species.

The dominance was the ratio of dominant group number and total species number [31]. The Jaccard formula [32] was used to calculate community similarity analysis of the ciliates that were from different soil samples:

$$
J=\frac{c}{(a+b-c)}
$$

where $J$ is similarity index; $a$ and $b$ are total number of species in sites 1 and 2, respectively; $c$ is the number of species common in both sites 1 and 2 .

The stepwise regression analysis was conducted to reveal the integrated effect of multifactors on soil ciliate abundance and the correlation degree between these factors and ciliate abundance [33]. The hierarchical cluster was conducted to analyze the similarity of physicochemical characters of 3 sampling sites. All statistical analyses were performed using SPSS 13.0 software.

\section{Results}

3.1. Physical/Chemical Parameters of Soil Samples in the Mangrove Forest. The main physical and chemical parameters at the three habitats of the mangrove forest measured with samples collected in April 2006 as environmental background are listed in Table 1. Some physical/chemical factors, such as water percentage, $\mathrm{OM}, \mathrm{TN}$, and $\mathrm{SO}_{4}{ }^{2-}$, are much different at different sampling sites. Others like $\mathrm{pH}$, salinity, TP and TK are slightly different. The hierarchical cluster dendrogram revealed that soil physical/chemical properties at bare land and Man-made mangrove are more similar; otherwise the Natural mangrove is disparate from other sites (Figure 2).
TABLE 2: Ciliate species found in all soil samples from the mangrove forest of Dongzhaigang, Hainan, China.

\begin{tabular}{|c|c|c|c|c|c|c|}
\hline \multirow{2}{*}{ Ciliate species } & \multicolumn{2}{|c|}{ Site A } & \multicolumn{2}{|c|}{ Site B } & \multicolumn{2}{|c|}{ Site C } \\
\hline & FS & DS & FS & DS & FS & DS \\
\hline Aspidisca steini & + & & + & & + & \\
\hline Colpoda cucullus & & & + & + & + & + \\
\hline Colpoda inflata & & & + & + & + & + \\
\hline Colpoda patella & & & & + & + & + \\
\hline Colpoda penardi & & & + & & + & + \\
\hline Colpoda reniformis & & & + & + & + & + \\
\hline Colpoda steinii & & & + & + & + & + \\
\hline Cyclidium elongatum & & & & & + & + \\
\hline Cyclidium simulans & & & & & + & + \\
\hline Cyrtolophosis bursaria & & & & & + & \\
\hline Cyrtolophosis major & + & & & & + & \\
\hline Diphrys appendiculata & + & & + & & + & \\
\hline Euplotes affinis & + & & + & & + & \\
\hline Euplotes bisulcatus & + & & & & & \\
\hline Euplotes elegans & + & & + & & + & \\
\hline Gonostomum affine & & + & + & + & + & + \\
\hline Gonostomum sp. & & + & & + & & \\
\hline Halteria grandinella & + & + & & + & + & + \\
\hline Holosticha adami & & & + & & + & \\
\hline Lacrymaria pupula & + & & & & + & \\
\hline Metopus es & + & + & & & + & + \\
\hline Metopus hasei & & + & & & + & + \\
\hline Oxytricha fallax & & + & & + & + & + \\
\hline Oxytricha marina & & & & + & & + \\
\hline Paruroleptus caudatus & & + & & & + & + \\
\hline Plagiocampa atra & + & & + & & + & \\
\hline Plagiocampa longis & + & & + & & + & \\
\hline Strombidium elegans & + & + & + & + & & + \\
\hline Strombidium fourneleti & + & & & & & + \\
\hline Strombidium stylifer & + & + & + & & + & + \\
\hline Strombidium sulcatum & + & & & + & & + \\
\hline Tachysoma pellionella & + & + & & + & & \\
\hline Trachelostyla caudata & & & & & + & + \\
\hline Uroleptus caudatus & & + & & + & + & \\
\hline Uroleptus dispar & & + & & + & + & + \\
\hline Urotricha agilis & + & & & & + & \\
\hline Vorticella aequilata & & & + & + & + & + \\
\hline Vorticella cupifera & & & & + & + & + \\
\hline
\end{tabular}

FS: fresh soil samples; DS: dried soil samples; + : detected in this sample

3.2. Community Structure of Soil Ciliates in Mangrove Forest. Three Classes, 11 Orders, 34 Genera, and 70 species of ciliates were found in all soil samples (Table 2). The first dominant group was Hypotrichida (24 species) with dominance of 0.34 , followed by Colpodida (14 species) with dominance of 0.2 . These two Orders together contributed more than half of the total species identified in the present study. The Sessilinia (Peritrichia) were represented by eight species. 
TABle 3: Comparison of the ciliate abundance and biodiversity indices in the mangrove forest from Dongzhaigang, Hainan, China.

\begin{tabular}{lcccc}
\hline \multirow{2}{*}{ Sites } & \multicolumn{2}{c}{ Average abundance $\left(\right.$ ind. $\mathrm{g}^{-1}$ ) } & \multicolumn{2}{c}{ Biodiversity indices } \\
& FS & DS & FS & DS \\
\hline Site A & 4,630 & 114 & 2.25 & 2.32 \\
Site B & 7,080 & 1,800 & 2.03 & 2.13 \\
Site C & 13,770 & 2,920 & 5.88 & 2.76 \\
\hline
\end{tabular}

FS: fresh soil samples; DS: dried soil samples.

3.3. Ciliate Abundance and Biodiversity. Table 3 shows that the abundance of soil ciliates in three habitats declined in the order Site A < Site B < Site C. The abundance of ciliates was the highest in the fresh sample from Site $C$, reaching 13,770 ind. $\mathrm{g}^{-1}$, while the lowest one was found in the dried sample from Site A, with only 114 ind. $\mathrm{g}^{-1}$. Results also indicated that the Margalef's biodiversity index of all samples ranged from 2 to 3 except the fresh sample from Site C. The biodiversity index of ciliates in both fresh and dried samples also varied among three habitats, followed the order of Site $\mathrm{B}<$ Site $\mathrm{A}<$ Site $\mathrm{C}$. The difference was more obvious in fresh samples (the discrepancy was 3.12) than that in dried samples.

3.4. Ciliate Community Similarity Indices. The ciliate community similarity indices ranged from 0.18 to 0.26 (fresh samples) and from 0.38 to 0.54 (dried sample) (Table 4). It was larger in dried samples than that in fresh ones. The order of similarity index in fresh samples followed Site A \& Site $\mathrm{C}<$ Site B \& Site C < Site A \& Site B, while the order was slightly different in dried samples (Site A \& Site $C<$ Site A \& Site B $<$ Site B \& Site C).

\subsection{Relationship between Ciliate Abundance and Physical/Chemical Properties in Soil}

3.5.1. Correlation in Fresh Samples. According to multiple stepwise regression analysis, the ciliate abundance was negatively correlated with $\mathrm{pH}$, but the relationships with soil moisture and salinity were positive (Table 5). Among these three factors, the most significant factor was $\mathrm{pH}$, followed by soil moisture, and the last was salinity. The ciliate abundance was also positively correlated with $\mathrm{OM}$, TN, TP, and $\mathrm{SO}_{4}{ }^{2-}(P<.01)$, but negatively correlated with TK $(P<.05)$. The effect of TN on the ciliate abundance was the largest, followed by TP, OM, and $\mathrm{SO}_{4}{ }^{2-}$, and TK showed the least effect.

3.5.2. Correlation in Dried Samples. Similar to that in fresh samples, negative correlation between ciliate abundance and $\mathrm{pH}$ but positive with moisture and salinity was found in dried samples (Table 6). However, the most influencing factor on ciliate abundance in dried samples was soil moisture, not $\mathrm{pH}$, slightly different from that in fresh samples. The relationships between ciliate abundance and soil chemical properties, namely, OM, TN, TP $\mathrm{SO}_{4}{ }^{2-}$, and $\mathrm{TK}$, were all positive except TK, the same trend as that in fresh samples.
TABLE 4: Comparison of ciliate community similarity indices between the habitats/sites from Dongzhaigang mangrove forest, Hainan, China.

\begin{tabular}{lcc}
\hline Sites & \multicolumn{3}{c}{ Similarity indices } \\
& FS & DS \\
\hline Site A \& Site B & 0.26 & 0.38 \\
Site A \& Site C & 0.18 & 0.35 \\
Site B \& Site C & 0.25 & 0.54 \\
\hline
\end{tabular}

FS: fresh soil samples; DS: dried soil samples.

Among these five factors on ciliate abundance, TP was most significant, followed by $\mathrm{TN}, \mathrm{SO}_{4}{ }^{2-}$, and $\mathrm{OM}$, and the effect of TK was the least.

\section{Discussion}

4.1. Analysis of Ciliate Communities in Different Habitats. The dominant groups in soils from Sites B and C were Hypotrichida and Colpodida which were similar with those in other terrestrial soil samples in China [35]. The ciliate species of Colpodida were found in most soil samples from all over the world [17, 19, 21, 34, 37-39]. With their flat body, Hypotrichida ciliates could not only swim in water, but also creep adjacent to soil granules or litters [35]. In addition, Hypotrichida and Colpodida ciliates had special adaptive strategies in their life cycles; for example, they were easy to encyst when the soil moisture decreased but they could excyst to recover their normal morphology if the soil was rewetted again $[21,39]$. Such biological characteristics allow these two groups of ciliates to adapt to intertidal mangrove soil where the habitat is alternately submerged and exposed conditions. It also helps to explain why Hypotrichida and Colpodida, which are common in terrestrial soils, are also dominant in mangrove soil habitats. However, the dominant group in Site A was the Oligotrichida and not Colpodida, suggesting that the habitat of Site A was different from terrestrial soils. Oligotrichida ciliates, especially Halteria spp., were generally considered as planktonic ciliate species. Site A, the bare land in the most seaward location, had lower terrain and the soil was more frequently covered by tidal seawater than the other sites. It is also possible that some planktonic ciliate species were brought to Site A by incoming tides. Oligotrichida ciliates were the uppermost consumers of algae and bacteria in aquatic environments and played a very important role in aquatic food webs because of their expansive feeding, rapid growing, swift moving, and strong activity [40].

When compared with other studies on the ciliate community in literatures, the percentages of Colpodids and Spirotrichs in Dongzhaigang mangrove soils were higher than those in Africa soil, Antarctic soil, and freshwater assemblage but were similar to those in Australia soil and world soil list (Table 7), indicating that the mangrove soil ciliates contained a representative subset of the world soil ciliate fauna [34]. According to Foissner [15], ciliate distribution in soil was correlated with morphological and ecological peculiarities of respective ciliate groups. Similar 
TABLE 5: Correlation of ciliate abundance (ind. $\left.\mathrm{g}^{-1}\right)$ ) with soil physical/chemical properties in fresh samples.

\begin{tabular}{|c|c|c|c|c|c|}
\hline & Factors & Correlation & Formulas of stepwise regression & $R^{2}$ & $P$ value \\
\hline \multirow{3}{*}{ Physical factors } & $\mathrm{pH}(p H)$ & $-{ }^{\mathrm{a}} 1^{\mathrm{b}}$ & $A b=43122.15-5927.667 p$ & 0.934 & .002 \\
\hline & Soil moisture $(S M)$ & +2 & $A b=-7286.268+442.911 S M$ & 0.922 & .002 \\
\hline & Salinity $(S)$ & +3 & $/ \mu^{c}$ & I & $>.05$ \\
\hline \multirow{5}{*}{ Chemical factors } & $\mathrm{OM}(\mathrm{OM})$ & +3 & $A b=3162.637+71.091 O M$ & 0.946 & .001 \\
\hline & $\mathrm{TN}(T N)$ & +1 & \multirow{2}{*}{$A b=-11879.4+2170.297 T N+26775.13 T P$} & \multirow{2}{*}{0.979} & .002 \\
\hline & $\mathrm{TP}(T P)$ & +2 & & & .012 \\
\hline & $\mathrm{SO}_{4}{ }^{2-}(\mathrm{SO})$ & +4 & $A b=1634.473+2300.289 S O$ & 0.918 & .003 \\
\hline & TK $(T K)$ & -5 & $A b=73563.27-5390.347 T K$ & 0.701 & .038 \\
\hline
\end{tabular}

a + means positive correlation; - means negative correlation.

${ }^{\mathrm{b}}$ Correlation degree ( 1 means the largest effect on ciliates abundance, followed 2, 3, in sequence).

${ }^{\mathrm{C}}$, no data.

TABLE 6: Correlation of ciliate abundance with soil physical/chemical properties in dried samples.

\begin{tabular}{|c|c|c|c|c|c|}
\hline & Factors & Correlation & Formulas of stepwise regression & $R^{2}$ & $P$ value \\
\hline \multirow{3}{*}{ Physical factors } & $\mathrm{pH}(p H)$ & $-{ }^{\mathrm{a}} 2^{\mathrm{b}}$ & & & .002 \\
\hline & Soil moisture $(S M)$ & +1 & $N u m=2825.583+94.947 W-779.06 p+19.107 S$ & 0.966 & .006 \\
\hline & Salinity $(S)$ & +3 & & & .048 \\
\hline \multirow{5}{*}{ Chemical factors } & $\mathrm{TP}(T P)$ & +1 & $N u m=-12599.7+25592.82 \mathrm{TP}$ & 0.959 & .001 \\
\hline & $\mathrm{TN}(T N)$ & +2 & $N u m=-467.485+1063.69 T N$ & 0.937 & .002 \\
\hline & $\mathrm{SO}_{4}{ }^{2-}(\mathrm{SO})$ & +3 & $N u m=-279.373+770 S O$ & 0.893 & .004 \\
\hline & $\mathrm{OM}(\mathrm{OM})$ & +4 & $N u m=265.429+23.383 O M$ & 0.888 & .005 \\
\hline & $\mathrm{TK}(T K)$ & -5 & $N u m=24242.76-1841.423 T K$ & 0.710 & .035 \\
\hline
\end{tabular}

${ }^{a}+$ means positive correlation; - means negative correlation.

${ }^{\mathrm{b}}$ correlation degree (1 means the biggest effect on ciliates abundance, followed 2, 3, in sequence).

TABle 7: Comparison (\%) of the taxonomic composition of the faunas investigated with the world list of soil ciliates and a representative freshwater ciliates assemblage.

\begin{tabular}{lcccccc}
\hline Ciliate groups & & \multicolumn{3}{c}{ Soil $(\%)^{*}$} & & Freshwater assemblage \\
& Dongzhaigang & Africa & Australia & Antarctica & World list & 30.3 \\
\hline Spirotrichs & 45.7 & 39.3 & 40.5 & 25.8 & 40.0 & 3.0 \\
Colpodids & 20.0 & 16.4 & 18.2 & 27.4 & 23.0 & 3.0 \\
\hline
\end{tabular}

${ }^{*}$ All data except data from Dongzhaigang, Hainan, China were from Foissner [34].

TABLE 8: Relationship comparison of soil ciliate abundance on physical/chemical factors between mangrove soil habitats and terrestrial soil habitats.

\begin{tabular}{|c|c|c|c|c|}
\hline & \multirow{2}{*}{ Factors } & \multicolumn{2}{|c|}{ Habitat in mangrove forest } & \multirow{2}{*}{ Habitat in terrestrial soil of China* } \\
\hline & & FS & DS & \\
\hline \multirow{3}{*}{ Physical factors } & $\mathrm{pH}$ & $-{ }^{\mathrm{a}} 1^{\mathrm{b}}$ & -2 & $+3^{c}$ \\
\hline & Soil moisture & +2 & +1 & +1 \\
\hline & Salinity & +3 & +3 & $/ \mathrm{d}$ \\
\hline \multirow{5}{*}{ Chemical factors } & $\mathrm{OM}$ & +3 & +4 & +1 \\
\hline & $\mathrm{TN}$ & +1 & +2 & +2 \\
\hline & $\mathrm{TP}$ & +2 & +1 & +3 \\
\hline & $\mathrm{SO}_{4}{ }^{2-}$ & +4 & +3 & I \\
\hline & TK & -5 & -5 & -4 \\
\hline
\end{tabular}

* Data from Ning and Shen $[35,36]$.

a + ; positive correlation; -; negative correlation.

${ }^{\mathrm{b}}$ Correlation degree ( 1 means the largest effect on ciliates abundance, followed 2, 3, in sequence).

${ }^{\mathrm{C}}$ Number 2 is temperature.

d/, no data. 
relationship was also demonstrated in ciliate distribution in mangrove forest soil in this study.

Some common ciliate species widely distributed all over the world such as Gonostomum affine and Colpoda spp. were also found at large abundance in soil samples collected in the present study (except Site A). In Namibia, West Africa, Gonostomum affine was found in 45 out of 73 samples while Colpoda steinii was present in 66 samples except the salt land samples with Cyanobacteria [39]. The frequencies of Colpoda cucullus and Colpoda inflata were also high in Antarctica [37]. As pointed out by Finlay et al. [41, 42 ], ciliate species that were locally rare or abundant were similarly rare or abundant on a global scale. For example, Gonostomum affine and Colpoda spp. could be considered as cosmopolitan ciliate species in all soil samples with different locations and environments, due to their morphological and distribution characteristics. In the present study, these ciliates were also dominant in mangrove forest soils, suggesting that Finlay's conclusion could be applied to this kind of soil habitat.

\subsection{Differences of Soil Ciliate Composition among Three} Mangrove Habitats. The architecture of the habitable soil pore network, which was determined by soil texture and structure, and the soil moisture were the most important factors determining the composition of soil ciliates. Their interaction established the basic environmental condition for soil ciliates [14]. Vargas and Hattori [43] showed that the aggregate structure of soil would effectively restrict ciliate movement, and only if the soil moisture was sufficiently high, their movement from one aggregate to another would be possible. Therefore, the ciliate fauna from different aggregates in the same soil may differ greatly.

In the present study, significant differences in ciliate composition and biodiversity were found among three mangrove habitats. The differences could be explained by special characteristics of Vargas' aggregates [43]. Although the three habitats were just separated by a small distance $(100 \mathrm{~m})$, their physical/chemical circumstances were so different leading to different vegetation and different soil aggregates. Firstly, the soil structure and texture of topsoil in Site C (natural mangroves) was very loose so that more ciliate species could exist there especially the big individuals. On the contrary, Site A (bare land) was made up of just compact mud, and around $50 \%$ of the soil granules had diameter less than $0.002 \mathrm{~mm}$. Such soil texture was fine and lacked many suitable pores for mobile ciliates and ciliate activity [44]. Secondly, the soil moisture in Site $\mathrm{C}$ was significantly higher than that in Site A; the values in Sites A, B, and C were $24.2 \%, 35.6 \%$, and $45.4 \%$, respectively. It was reported that soil moisture was a main restricting factor on the survival, multiplication, and distribution of soil protozoan in the Fildes Peninsula, Antarctica [45]. High soil moisture in Site $\mathrm{C}$ explained why ciliate species were more abundant and biodiversity was higher in this habitat than the other two sites. Thirdly, plenty of organic residues and the plant litters were found in bottom mud in Site C (natural mangroves). Litters not only supplied sufficient organic matter, humus and other nutrients to soil ciliate, but also allowed greatly ciliate mobility (especially for Hypotrichida ciliates). Lastly, the synergic effect of several factors, such as $\mathrm{pH}$, salinity, and temperature, would enhance the differences among different mangrove soil aggregates/habitats.

\subsection{Effect of Drying Samples on Ciliate Abundance and Com-} position. It has often been assumed that direct microscopic examination of soil would result in an unreliable picture of the populations of ciliates, because their numbers are relatively small and they cannot be readily separated from the soil particles [46]. On the other hand, most soil ciliates have the ability to encyst, which can protect themselves against adverse conditions [14]. Although the MPN method is commonly used for enumerating soil ciliates, this method suffers from serious shortcomings. It might underestimate total protozoan numbers if the organisms were killed during the setting up of the cultures [47], or if they were unable to grow on the food offered. It is also possible that this method cannot reactivate all cysts and the species present; for example, the real number of species in the sample was very likely considerably higher than that in MPN [34]. The soil samples from the three different habitats were determined by MPN and compared with the direct counting method. The ciliate abundance in fresh samples was much greater than that in dried samples, suggesting that some ciliates failed to encyst or to excyst after air-drying, which caused direct decreases of ciliate abundance. In the other hand, the decrease of bacteria (serving as ciliate food) in dried samples might indirectly affect the ciliate abundance. In this study, the ciliate species which were abundant in fresh samples but disappeared in dried samples were Euplotes, Diphrys, Cyrtolophosis, and Plagiocampa, indicating that these species had lower ability to encyst or excyst than the other ciliates such as Colpoda and Gonostomum. Similar findings were also reported by Foissner [19]. The present data on the composition and abundance of ciliates proved that for more detailed information of soil ciliate community, the MPN and other methods for soil ciliate analysis should be used together.

\subsection{Relationship between Ciliate Abundance and Soil Physical/} Chemical Factors. Although the effects of one physical/ chemical-factor on ciliates have been widely studied [14, 43 , $45,48-50]$, reliable data on multiple effects or interactions of several physical/chemical factors are extremely rare. In this study, an integrated effect of multifactors on the soil ciliate of mangrove forest soils showed that the correlations between ciliate abundance and physical/chemical factors were similar to those in terrestrial habitats except for $\mathrm{pH}$ values (Table 8). Under the salty condition in mangrove forest habitats, the acidic $\mathrm{pH}$ favored the protozoan osmotic regulation and nutrient absorption and explained why the ciliate abundance was negatively correlated with $\mathrm{pH}$.

4.5. Relationship between the Ciliate Community Similarity Indices and the Mangrove Ecological Restoration. Ning and Shen [36] explained the important significance of community similarity indices and biodiversities by reflecting the complexity and stability of communities themselves and 
the ecological or environmental quality. The soil ciliate similarity index between habitats was very low (appeared quite dissimilar or a little dissimilar), which not only supported the opinion that different aggregates had different protozoan biodiversities $[43,51]$ but also showed the significant effects of vegetation and soil physical/chemical factors on soil protozoan communities. In this study, results of ciliate community similarity index proved that ciliate community in Site B was between Sites A and C. In fact, Site B (artificially planted mangroves) was the transitional stage from Site A (bare land) to Site C (natural mangroves) in a mangrove forest. Thus, we can deduce the evolvement of different mangrove soils and the mangrove vegetation restoration through their similarity indices. The soil ciliate community could be used to assess the restoration of the mangrove ecosystem.

\section{Acknowledgment}

Jing Li and Qingyu Liao contributed equally to this paper. This work was supported by the National Natural Scientific Foundation (Project U0633002). J. Li and Q. Liao contributed equally to this paper.

\section{References}

[1] D. A. Henley, "An investigation of proposed effluent discharge into a tropical mangrove estuary," in Proceedings of the International Conference on Water Pollution Control in Developing Countries, vol. 9, pp. 43-64, Bangkok, Thailand, 1978.

[2] F. Dahdouh-Guebas, L. P. Jayatissa, D. Di Nitto, J. O. Bosire, D. Lo Seen, and N. Koedam, "Erratum: how effective were mangroves as a defence against the recent tsunami? (Current Biology (2005) 15 (R443-R447))," Current Biology, vol. 15, no. 14, pp. 1337-1338, 2005.

[3] C. H. Lucero, J. R. Cantera, and I. C. Romero, "Variability of macrobenthic assemblages under abnormal climatic conditions in a small scale tropical estuary," Estuarine, Coastal and Shelf Science, vol. 68, no. 1, pp. 17-26, 2006.

[4] A. H. Dye, "Persistent effects of physical disturbance on meiobenthos in mangrove sediments," Marine Environmental Research, vol. 62, no. 5, pp. 341-355, 2006.

[5] D. Raut, T. Ganesh, N. V. S. S. Murty, and A. V. Raman, "Macrobenthos of Kakinada Bay in the Godavari delta, East coast of India: comparing decadal changes," Estuarine, Coastal and Shelf Science, vol. 62, no. 4, pp. 609-620, 2005.

[6] O. V. Sousa, A. Macrae, F. G. R. Menezes, N. C. M. Gomes, R. H. S. F. Vieira, and L. C. S. Mendonça-Hagler, "The impact of shrimp farming effluent on bacterial communities in mangrove waters, Ceará, Brazil," Marine Pollution Bulletin, vol. 52, no. 12, pp. 1725-1734, 2006.

[7] E. M. S. Brito, R. Guyoneaud, M. Goñi-Urriza, et al., "Characterization of hydrocarbonoclastic bacterial communities from mangrove sediments in Guanabara Bay, Brazil," Research in Microbiology, vol. 157, no. 8, pp. 752-762, 2006.

[8] Q.-H. Chen, N. F.-Y. Tam, P. K. S. Shin, S.-G. Cheung, and R.-L. Xu, "Ciliate communities in a constructed mangrove wetland for wastewater treatment," Marine Pollution Bulletin, vol. 58, no. 5, pp. 711-719, 2009.

[9] B. W. Hayward, H. R. Grenfell, A. D. Pullin, C. Reid, and C. J. Hollis, "Foraminiferal associations in the upper Waitemata
Harbour, Auckland, New Zealand," Journal of the Royal Society of New Zealand, vol. 27, no. 1, pp. 21-51, 1997.

[10] Q. Y. Liao, J. Li, J. H. Zhang, M. Li, Y. Lu, and R. L. Xu, "An ecological analysis of soil sarcodina at Dongzhaigang mangrove in Hainan Island, China," European Journal of Soil Biology, vol. 45, no. 3, pp. 214-219, 2009.

[11] J. H. Lipps and M. R. Langer, "Benthic foraminifera from the meromictic Mecherchar Jellyfish Lake, Palau (western Pacific)," Micropaleontology, vol. 45, no. 3, pp. 278-284, 1999.

[12] K. Christoffersen and J. M. González, "An approach to measure ciliate grazing on living heterotrophic nanoflagellates," Hydrobiologia, vol. 491, pp. 159-166, 2003.

[13] M. P. M. Janssen and G. J. S. M. Heijmans, "Dynamics and stratification of protozoa in the organic layer of a Scots pine forest," Biology and Fertility of Soils, vol. 26, no. 4, pp. 285-292, 1998.

[14] F. Ekelund and R. Rønn, "Notes on protozoa in agricultural soil with emphasis on heterotrophic flagellates and naked amoebae and their ecology," FEMS Microbiology Reviews, vol. 15, no. 4, pp. 321-353, 1994.

[15] W. Foissner, "Soil protozoa: fundamental problems, ecological significance, adaptations in ciliates and testaceans, bioindicators, and guide to the literature," Progress in Protistology, vol. 2, pp. 69-212, 1987.

[16] W. Foissner, "Protozoa as bioindicators in agroecosystems, with emphasis on farming practices, biocides, and biodiversity," Agriculture, Ecosystems and Environment, vol. 63, no. 2-3, pp. 93-103, 1997.

[17] W. Foissner, "Soil protozoa as bioindicators: pros and cons, methods, diversity, representative examples," Agriculture, Ecosystems and Environment, vol. 74, no. 1-3, pp. 95-112, 1999.

[18] M. Li, L. J. Wang, W. H. Ma, and M. Hong, "Biological monitoring on water pollution in the Dongzhaigang national mangrove nature reserve," Journal of Hainan Normal University, vol. 9, pp. 282-285, 2004.

[19] W. Foissner, "Soil ciliates (Protozoa: Ciliophora) from evergreen rain forests of Australia, South America and Costa Rica: diversity and description of new species," Biology and Fertility of Soils, vol. 25, no. 4, pp. 317-339, 1997.

[20] Nanjing Institute of Soil Science and Chinese Academy of Sciences, Physical and Chemical Analysis of Soil, Shanghai Sci Technol, Shanghai, China, 1978.

[21] W. Foissner, Colpodea (Ciliophora), Gustav Fischer, Stuttgart, Germany, 1993.

[22] H. Berger, Monograph of the Oxytrichidae (Ciliophora, Hypotrichia), Kluwer Academic Publishers, Dordrecht, The Netherlands, 1999.

[23] P. G. Carey, Marine Interstitial Ciliates, Natural History Museum, London, UK, 1992.

[24] A. Kahl, Urtiere oder Protozoa I: Wimpertiere oder Ciliata (Infusoria), Gustav Fischer, Jena, Germany, 1935.

[25] J. J. Lee, G. F. Leedale, and P. Bradury, An Illustrated Guide to the Protozoa, Society of Protozoologists, Lawrence, Kan, USA, 2nd edition, 2000.

[26] Y. F. Shen and X. J. Gong, Aquatic Invertebrate in Tibet, Science Press, Beijing, China, 1983.

[27] Y. F. Shen, Z. S. Zhang, X. J. Gong, M. R. Gu, Z. X. Shi, and Y. X. Wei, New Monitoring Technology of Microbiology, Chinese Architectural Industry Press, Beijing, China, 1990.

[28] W. B. Song, Monograph of Protozoology, Qingdao Ocean University Press, Qingdao, China, 1999.

[29] J. F. Darbyshire, R. E. Wheatley, M. P. Greaves, and R. H. E. Inkson, "A rapid micromethod for estimating bacterial and 
protozoan populations in soil," Revue d'Ecologie et de Biologie du Sol, vol. 11, pp. 465-475, 1974.

[30] D. R. Margalef, "Information theory in ecology," General Systems, vol. 3, pp. 36-71, 1958.

[31] Y. Z. Ning and Y. F. Shen, "Soil protozoa," Bulletin of Biology, vol. 31, pp. 13-15, 1996 (Chinese).

[32] W. P. McCormick, N. I. Lyons, and K. Hutcheson, "Distributional properties of Jaccard's index of similarity," Communications in Statistics, vol. 21, pp. 51-68, 1992.

[33] J. Li, M. G. Li, J. Yang, C. F. Wang, Y. Ai, and R. L. Xu, “The community structure of soil Sarcodina in Baiyun Mountain, Guangzhou, China," European Journal of Soil Biology, vol. 46, no. 1, pp. 1-5, 2010.

[34] W. Foissner, "Global soil ciliate (Protozoa, Ciliophora) diversity: a probability-based approach using large sample collections from Africa, Australia and Antarctica," Biodiversity and Conservation, vol. 6, no. 12, pp. 1627-1638, 1997.

[35] Y. Z. Ning and Y. F. Shen, "Soil protozoa in typical zones of China: I. Studies on faunal characteristics and distribution of species," Acta Zoologica Sinica, vol. 44, pp. 5-10, 1998 (Chinese).

[36] Y. Z. Ning and Y. F. Shen, "Soil protozoa in typical zones of China: II. Ecological study," Acta Zoologica Sinica, vol. 44, pp. 271-276, 1998 (Chinese).

[37] W. Foissner, "Faunistics, taxonomy and ecology of moss and soil ciliates (protozoa, ciliophora) from Antarctica, with description of new species, including Pleuroplitoides smithi gen. n., sp. n." Acta Protozoologica, vol. 35, no. 2, pp. 95-123, 1996.

[38] W. Foissner and I. Foissner, "First record of an ectoparasitic flagellate on ciliates: an ultrastructural investigation of morphology and the mode of attachment of Spiromonas gonderi nov. spec. (Zoomastigophora, Spiromonadidae) invading the pellicle of ciliates of the genus Colpoda (Ciliophora, Colpodidae)," Protistology, vol. 20, pp. 635-648, 1984.

[39] W. Foissner, S. Agatha, and H. Berger, Soil Ciliates (Protozoa, Ciliophora) from Namibia (Southwest Africa), with Emphasis on Two Contrasting Environments, the Etosha Region and the Namib Desert. Part 1: Text and Line Drawing. Part 2: Potographs, vol. 5, Denisia, Linz, Austria, 2002.

[40] K. Šimek, K. Jürgens, J. Nedoma, M. Comerma, and J. Armengol, "Ecological role and bacterial grazing of Halteria spp.: small freshwater oligotrichs as dominant pelagic ciliate bacterivores," Aquatic Microbial Ecology, vol. 22, no. 1, pp. 43$56,2000$.

[41] B. J. Finlay, G. F. Esteban, and T. Fenchel, "Protist diversity is different?" Protist, vol. 155, no. 1, pp. 15-22, 2004.

[42] B. J. Finlay, G. F. Esteban, K. J. Clarke, and J. L. Olmo, "Biodiversity of terrestrial protozoa appears homoqeneous across local and global spatial scales," Protist, vol. 152, no. 4, pp. 355-366, 2001.

[43] R. Vargas and T. Hattori, "The distribution of protozoa among soil aggregates," FEMS Microbiology Ecology, vol. 74, no. 1, pp. 73-77, 1990.

[44] J. F. Darbyshire, L. Robertson, and L. A. Mackie, "A comparison of two methods of estimating the soil pore network available to protozoa," Soil Biology and Biochemistry, vol. 17, no. 5, pp. 619-624, 1985.

[45] W. S. Feng and Y. H. Yu, "Ecological research of soil protozoa in the Fildes Peninsula in Antarctica," Acta Hydrobiologica Sinica, vol. 24, pp. 610-615, 2000 (Chinese).

[46] B. N. Singh, "Culturing soil protozoa and estimating their numbers in soil," in Soil Zoology, D. K. McKevan, Ed., pp. 403411, Butterworths Scientific, London, UK, 1955.
[47] B. S. Griffiths and K. Ritz, "A technique to extract, enumerate and measure protozoa from mineral soils," Soil Biology and Biochemistry, vol. 20, no. 2, pp. 163-173, 1988.

[48] T. A. Forge, E. Hogue, G. Neilsen, and D. Neilsen, "Effects of organic mulches on soil microfauna in the root zone of apple: implications for nutrient fluxes and functional diversity of the soil food web," Applied Soil Ecology, vol. 22, no. 1, pp. 39-54, 2003.

[49] V. V. S. R. Gupta and J. J. Germida, "Populations of predatory protozoa in field soils after 5 years of elemental s fertilizer application," Soil Biology and Biochemistry, vol. 20, no. 6, pp. 787-791, 1988.

[50] B. F. Sherr, E. B. Sherr, and F. Rassoulzadegan, "Rates of digestion of bacteria by marine phagotrophic protozoa: temperature dependence," Applied and Environmental Microbiology, vol. 54, pp. 1091-1095, 1988.

[51] R. Hattori and T. Hattori, "Soil aggregates as microcosms of bacteria-protozoa biota," Geoderma, vol. 56, no. 1-4, pp. 493$501,1993$. 

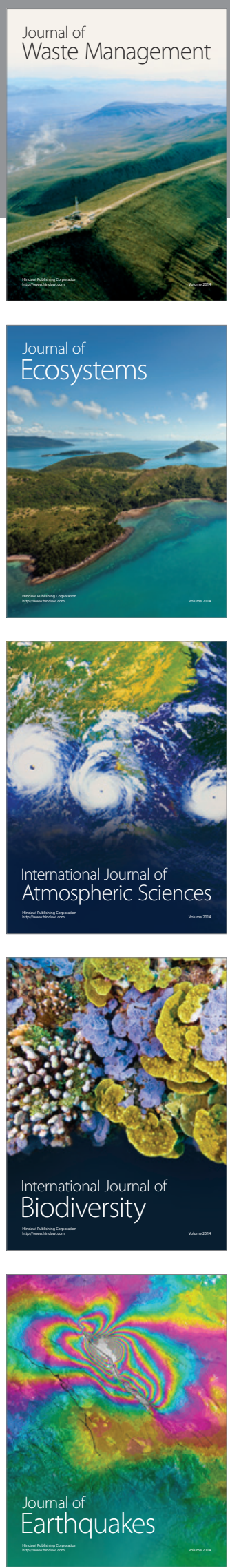
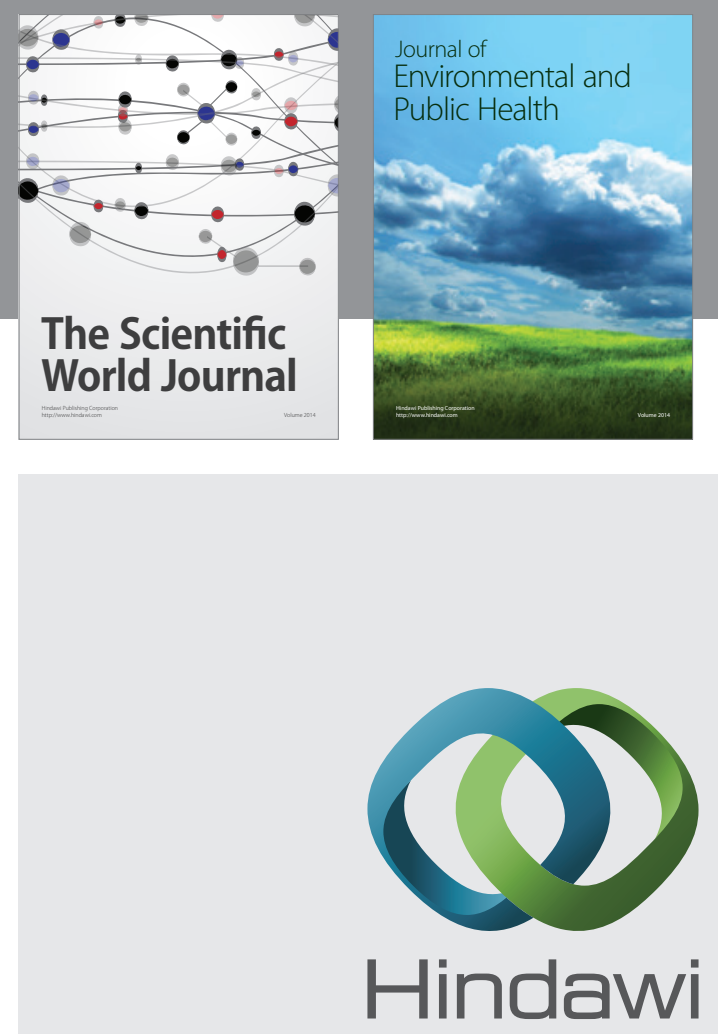

Submit your manuscripts at

http://www.hindawi.com
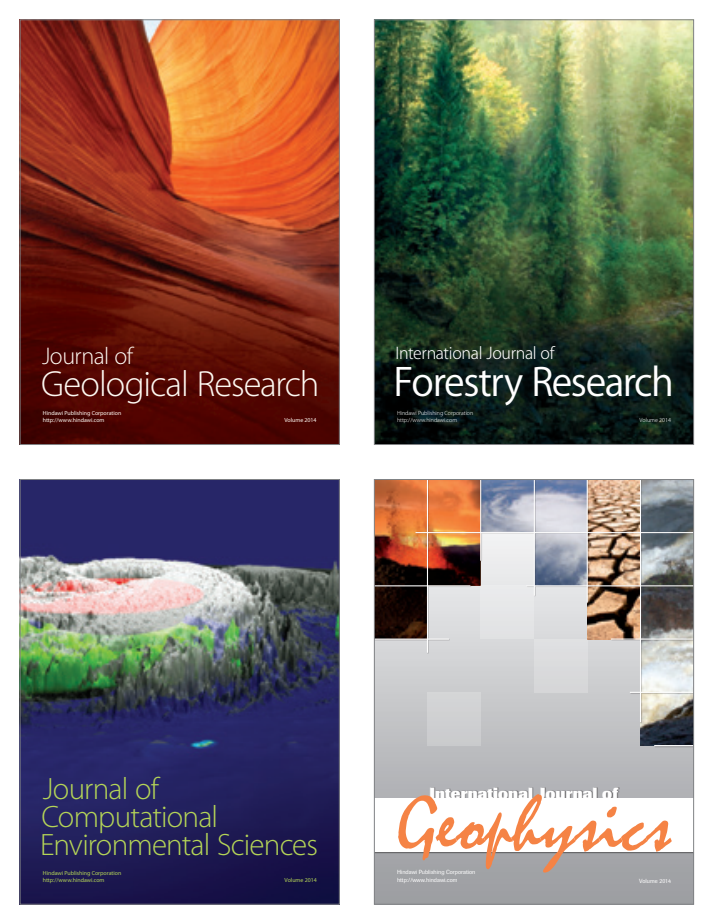
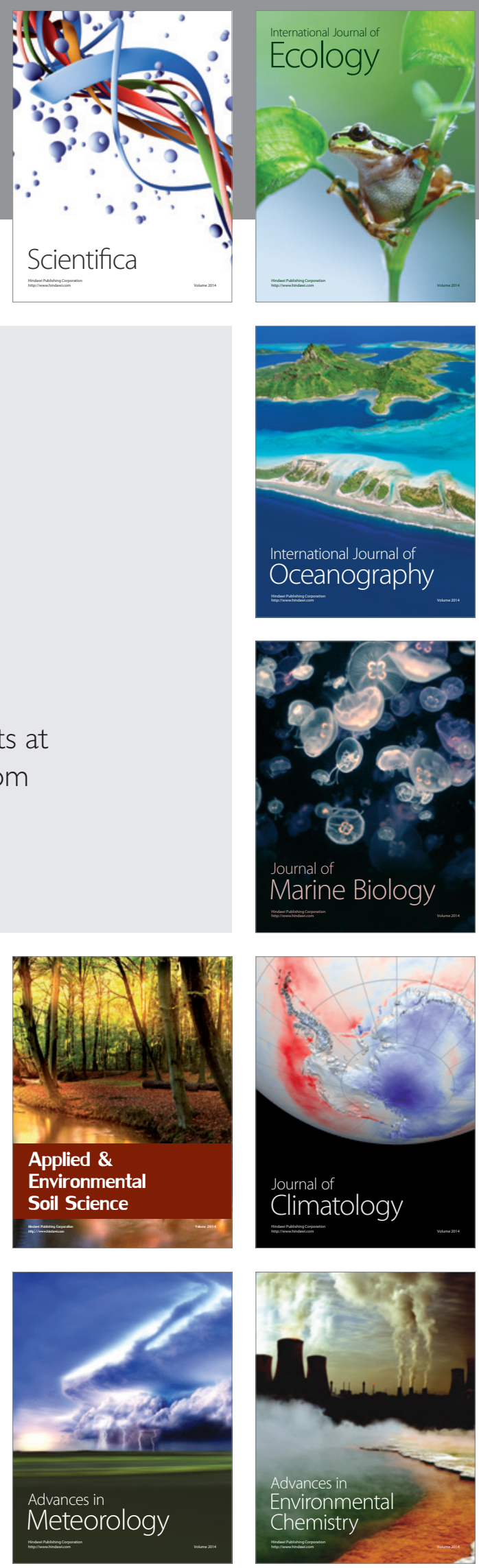